\title{
La representación de la tristeza y el caos a través de los elementos metafóricos de la naturaleza en Campos de castilla (1912) de Antonio Machado
}

\author{
Yordan Arroyo Carvajal \\ Universidad de Costa Rica, Costa Rica \\ yordan 846994@hotmail.com \\ https://orcid.org/0000-0002-2509-4918
}

Recibido: 2 de marzo 2018

Aceptado: 30 de mayo 2018

\section{Resumen:}

En este artículo se presenta un análisis en torno a los elementos del campo como por ejemplo, la tierra, los ríos, el pedregal, entre otros, que son utilizados de manera metafórica en Campos de Castilla (1912), para darle un matiz negativo o angustiante al espacio bucólico del poemario, que a su vez marca o influye en el estado de ánimo del yo lírico. En tal estudio se toma en cuenta el convulso contexto socio-histórico de fondo en España durante finales del siglo XIX e inicios del XX. Para asociar texto-sociedad se toma en cuenta la teoría de la sociocrítica, A su vez, los elementos de la naturaleza, inmersos en el poemario son analizados a partir del simbolismo, utilizándose como base los diccionarios de símbolos de Chevalier y de Cirlot.

Palabras clave: Naturaleza; símbolos; metáforas; caos; nostalgia.

The representation of sadness and chaos through the metaphorical elements of nature in Campos de castilla (1912) by Antonio Machado

\section{Abstract:}

In this article an analysis is presented around the elements of the field such as, for example, the earth, the rivers, the scree, among others, that are used metaphorically in Campos de Castilla (1912), to give a negative nuance or distressing the bucolic space of the poems, which in turn marks or influences the mood of the lyric self. In this study, we take into account the convulsive sociohistorical backdrop in Spain during the late nineteenth and early twentieth

\section{(c) (i) (2) (2)}

La Revista Estudios es editada por la Universidad de Costa Rica y se distribuye bajo una Licencia Creative Commons Atribución-NoComercial-CompartirIgual 3.0 Costa Rica. Para más información envíe un mensaje a 
Especial: Naturaleza amena y naturaleza agreste en las letras hispánicas centuries. In order to associate text-society, the theory of socio-criticism is taken into account. In turn, the elements of nature, immersed in the poems are analyzed from the symbolism, using as base the dictionaries of Chevalier and Cirlot symbols.

Keywords: Nature; symbols; metaphors; chaos; nostalgic.

\section{INTRODUCCIÓN}

En este artículo se toca el tema de la degradación de la naturaleza representada mediante símbolos y lo que ello afecta en los sentimientos del yo lírico en el poemario Campos de Castilla (1912), propiamente en los poemas Retrato y Por las tierras de España. A partir de lecturas de crítica, creadas en torno a Antonio Machado y su poesía, ha relucido que este poeta español juega mucho con el tema de los símbolos en relación con la nostalgia, la tragedia y la soledad, que son elementos particulares de su vida personal. Para respaldar ello cabe citar los siguientes versos:

Mi infancia son recuerdos de un patio de Sevilla, y un huerto claro donde madura el limonero; mi juventud, veinte años en tierra de Castilla; mi historia, algunos casos que recordar no quiero (Campos de Castilla, 1912).

En los versos citados se aprecia que el yo lírico extraña constantemente, sea su niñez, pasado, o personas que ya no están con él por motivos del destino, incluso su misma patria, que cada vez se ve más contaminada. Tal degradación ya había sido anunciada por Miguel de Cervantes en el Siglo XVII, quien a través del personaje de Sancho Panza, menciona en El Ingenioso Hidalgo Don Quijote de la Mancha (1605), que Dulcinea (símbolo de España), presenta un olor rancio y como a ajos, lo cual evidentemente es una crítica a la caída que ha empezado a tener uno de los imperios más grandes que ha tenido la historia, el español.

\section{(c) (i) (2)}

La Revista Estudios es editada por la Universidad de Costa Rica y se distribuye bajo una Licencia Creative Commons Atribución-NoComercial-CompartirIgual 3.0 Costa Rica. Para más información envíe un mensaje a 
Especial: Naturaleza amena y naturaleza agreste en las letras hispánicas

Incluso, la palabra limonero en la segunda estrofa es relevante porque según Cristinela Niculescu (2014), el limón tiene un sentido de limpieza que se analiza a fondo más adelante.

Debido a que la infancia de Antonio Machado y su desarrollo en vida se ve representado en su temática de escritura, es necesario conocer, un poco más a fondo, aspectos biográficos de él, para acercarse a asuntos históricos, sociales e ideológicos que repercuten de manera ineludible en la vida, no solo de Antonio Machado, sino de todo autor. Tal asunto es respaldado por la crítica literaria, y por tanto, nombrado como sujeto transindividual por Edmond Cross tras aludir a otro crítico literario como lo es Lucien Goldmann.

Antonio Machado es un distinguido poeta español e integrante tardío de la famosa Generación del 98 española, la cual data a finales del siglo XIX, y que se describe más adelante. Sin embargo, a pesar de su llegada tardía a este grupo literario, esto no afectó en nada, puesto que es catalogado como uno de los más importantes del conjunto de poetas. Nació en Sevilla el 26 de julio de 1875 y murió, tras su exilio, en Francia, un 22 de febrero de 1939, justamente en el año que da inicio la Segunda Guerra Mundial (Literatura Española del siglo XX, s.f).

No obstante, la mayor parte de criterios señala que la mayoría de sus obras apuntan en función del Modernismo, lo cual tiene coherencia puesto que en sus poemas se denota mucho la idea de trascender en el futuro, tras mirarse al pasado con mucha nostalgia, es decir, como una época que fue mejor y que se ha degradado con la llegada de la modernidad. Sin embargo, en tanto criterio personal, Antonio Machado decía que él no quería que se le encajara dentro de un solo movimiento literario, debido a que eso era restringirlo, Machado decía tener un poco de cada movimiento literario dentro de su estilo (Literatura Española del siglo XX, s.f).

\section{(C) $(\Theta \odot$}

La Revista Estudios es editada por la Universidad de Costa Rica y se distribuye bajo una Licencia Creative Commons Atribución-NoComercial-CompartirIgual 3.0 Costa Rica. Para más información envíe un mensaje a 
Especial: Naturaleza amena y naturaleza agreste en las letras hispánicas

A su vez, según Literatura Española del Siglo XX (s.f), Antonio Machado viene de una familia que seguía la tendencia política liberal progresista, asunto que se vio reflejado en su escritura, en cuanto a críticas o quejas sociales (p.1). De paso, cabe decir que pocos años después de haber iniciado su proceso en el mundo de la literatura y haber conocido igual en Francia a Rubén Darío, Antonio Machado tuvo la posibilidad de formarse de muy buena manera en Madrid e inclusive estudiar filología francesa en Francia(Literatura Española del siglo XX, s.f, p.2).

Por su lado, el tema de la muerte en relación con seres queridos, al igual que en muchos de los grandes escritores de la historia, no fue caso omiso con Antonio Machado. Él tuvo que soportar el sufrimiento de haber perdido a Leonor ${ }^{1}$ en 1912 (Literatura Española del siglo XX, s.f, p.3), año en que se publica Campos de Castilla.

Dados los datos en torno a aspectos relevantes sobre el autor, cabe referirse al contexto en el que se vio inmerso Machado, puesto que ello marca su estilo de escritura y es indispensable conocer qué estaba sucediendo en ese entonces en España para entender mejor las metáforas y símbolos presentes en sus poemas.

Durante finales del siglo XIX, e inicios del siglo XX, en España había una serie de problemáticas que se mencionan en los siguientes párrafos. Antonio Machado se vio inmerso en un periodo en donde el poderío español tiene su caída por completo, porque a finales del siglo XIX el único dominio que tenían era sobre

\footnotetext{
${ }^{1}$ Leonor fue la esposa de Machado, ella enfermó de tuberculosis en 1911, lo cual hizo que ambos tuvieran que irse de Francia para hospedarse en Soria. (Literatura Española del siglo XX, s.f, p.3). 
Especial: Naturaleza amena y naturaleza agreste en las letras hispánicas

Cuba y lo pierden, justamente en $1898^{2}$, tras intervención norteamericana. (Casanova y Gil Andrés, 2012, pp.19-22).

Incluso, el contexto caótico al que se hace referencia, marca el nombre de la Generación del 98, justamente a la que pertenece Antonio Machado, conocida como la del desastre y de la que se habla más adelante. "En el siglo XIX era difícil encontrar a un Estado europeo que hubiera pasado por tantos pronunciamientos militares, revueltas populares, revoluciones y guerras civiles como los que sucedieron en España” (Casanova y Gil Andrés, 2012, p.22).

Ya en 1895 se presenta la conformación del Estado liberal en España. Según datos encontrados este Estado liberal se creó a partir de grandes desastres y conflictos. Buscaba seguir un modelo francés pero esto fue imposible, puesto que no lograba llegar a todos los lugares españoles, lo cual empezó a acrecentar la desigualdad. Además, a finales del siglo XIX se presentó la oposición de la iglesia ante propuestas del Estado, lo cual posibilitó la constante intervención del ejército en la vida civil española y un sistema oligárquico y caciquil muy opuestos a los parámetros democráticos (Casanova y Gil Andrés, 2012, pp.25-27).

Un dato alarmante es que iniciado el siglo XX el vivir en Europa era similar a estar en el infierno, no había esperanza de existir más de 35 años, ya que esta era la tasa promedio de vida, debido a la alta tasa de mortalidad, catástrofes y diversas problemáticas políticas y civiles. Además, la gran mayoría de niños recién nacidos no duraban más de un año, las difíciles condiciones de vida no les permitían vivir, había muy malas condiciones sanitarias e higiénicas junto con los pocos recursos para conseguir una buena alimentación. En fin, aparte de lo anterior, si la gente no moría por falta de recursos económicos, había cientos de epidemias en España como la viruela, el sarampión, el tifus y demás que se

\footnotetext{
${ }^{2}$ En este acontecimiento se da la muerte de muchos soldados españoles tras el contagio de enfermedades generadas en la isla (Casanova y Gil Andrés, 2012, pp.25-27).
}

La Revista Estudios es editada por la Universidad de Costa Rica y se distribuye bajo una Licencia Creative Commons Atribución-NoComercial-CompartirIgual 3.0 Costa Rica. Para más información envíe un mensaje a revistaestudios.eeg@ucr.ac.cr. 
ISSN 1659-3316

Especial: Naturaleza amena y naturaleza agreste en las letras hispánicas encargaban de quitar la vida de los españoles (Casanova y Gil Andrés, 2012, p.28).

Otro problema más, que se dio a inicios del siglo XX es el analfabetismo, puesto que de cada 100 ciudadanos adultos, 56 no sabían leer ni escribir, lo cual disminuía las posibilidades de progreso, esto se ve muy marcado junto con la dificultad de España de alcanzar el urbanismo, la mayoría de los sitios españoles eran rurales. (Casanova y Gil Andrés, 2012, p.29). Recuérdese que Machado había tenido la posibilidad de estudiar y además pudo trasladarse a Francia en donde se vio muy bien influenciada su educación.

Empero, a pesar de todas las problemáticas, presentes en el siglo $\mathrm{XX}$ en España, no se debe dejar de lado que en comparación con años anteriores, este país alcanzó un progreso que partía mucho del ingreso mercantil, el detalle está en que su desarrollo se dio muy lento, debido a que, no en todas las zonas españolas había los mismos recursos, había sitios en donde la escases de elementos, como por ejemplo, el agua, era constante y drástico (Casanova y Gil Andrés, 2012, p.29).

Otro serio problema y de mala administración política durante el siglo $\mathrm{XX}$ era que, debido a la falta de policías, cualquier problema, por mínimo que fuera, quedaba a correspondencia del ejército español, lo cual generaba un entorno muy violento en donde las medidas para resolver los problemas no eran las mejores ni más adecuadas, además, tales bárbaras medidas, incrementaban los niveles de protesta en las clases populares, en donde la gente empezó a buscar sus propias soluciones para no verse tan afectados y erradicar así las muertes, balaceras y demás asuntos en la zona (Casanova y Gil Andrés, 2012, p.29).

Enseguida, se empezaron a crear movimientos, como por ejemplo, el realizado en 1890 por un grupo de obreros y que se le llamó la fiesta del trabajo.

La Revista Estudios es editada por la Universidad de Costa Rica y se distribuye bajo una Licencia Creative Commons Atribución-NoComercial-Compartirlgual 3.0 Costa Rica. Para más información envíe un mensaje a revistaestudios.eeg@ucr.ac.cr. 
Especial: Naturaleza amena y naturaleza agreste en las letras hispánicas

La anarquía empezó a crecer hasta que desapareció la Primera República, ello borró todo tipo de esperanza en torno a la creación o crecimiento de la organización de masas, que tenían el afán de combatir el poder estatal, a través de la propuesta de una democratización, que no se hizo realidad y por tanto pasó a formar parte de la historia del siglo XX en España, porque con los años la situación empeoró y tiempo después vendría la dictadura de Francisco Franco (Casanova y Gil Andrés, 2012, pp.31-33).

En síntesis, en cuanto a parte socio-histórica, Literatura del siglo $X X$ (s.f), realiza un resumen en donde se argumenta que entre mediados del siglo XIX y entrada del siglo XX la mayor problemática en España fue la inestabilidad política, lo cual es drástico, porque de ello es justamente de donde subyacen todos los problemas mencionados en los párrafos anteriores, como por ejemplo, hambrunas, violentas manifestaciones sociales en donde tiene cabida la clase obrera, epidemias, desigualdad, entre otras.

A su vez, en todos los problemas socio-históricos anteriores, se encuentra vinculada la pérdida absoluta de la colonia española en 1898, fecha en donde, como se indicó con anterioridad, inicia la época del desastre, que, a partir de los datos encontrados, queda cada vez más claro que es fuente primaria de creación de Campos de Castilla (1912), para la psicología del autor.

Además el caos en España durante finales del siglo XIX es motivo de creación de la Generación del 98. En este convulso periodo, en cuanto poesía, se cuestiona el presente, añora el pasado y se trata de escapar de la realidad a través de la belleza de los poemas. Inclusive se menciona que en este ciclo, Antonio Machado, "inició la poesía española contemporánea mezclando la seriedad reflexiva, la profunda meditación temporal y motivos cívicos con el simbolismo" (Literatura del Siglo XX, s.f).

\section{(c) (i) (9) (2)}

La Revista Estudios es editada por la Universidad de Costa Rica y se distribuye bajo una Licencia Creative Commons Atribución-NoComercial-CompartirIgual 3.0 Costa Rica. Para más información envíe un mensaje a 
Especial: Naturaleza amena y naturaleza agreste en las letras hispánicas

Tras tener claro el contexto en el que se crea el poemario de Antonio Machado, es relevante presentar lo que es la Generación a la cual él perteneció y posterior a ello una muestra de lo que se ha dicho sobre su poemario en estudio.

\section{GENERACIÓN DEL 98 ESPAÑOLA}

La Generación del 98, de acuerdo con Innman (1989, p. 1761), es el nombre con el que se conoce a un grupo de escritores e intelectuales españoles de quienes se hablaba en 1899. Es una generación nacida a raíz de la crisis que sufrió España a finales del siglo XIX.

Los poetas de la Generación del 98, también conocida como la «generación del desastre», salieron a la luz en 1898. Sus obras significaron un grito en contra de los engaños de España en cuanto temas como política, prensa, literatura, oligarquía, ciencia, etc. (Innman, 1989, p. 1762). Estos dioses de la escritura, en consecuencia, fueron considerados como reformadores de la política y de la cultura de España. Al mismo tiempo se trataba de una generación literaria, que se ha asociado con el Modernismo.

Las obras de estos escritores se han visto como una ruptura de las tendencias anteriores, pero un rompimiento que responde a los sentimientos de vergüenza y dolor a causa de los desastres ocurridos en España, principalmente los vinculados con las prácticas viciosas de la política.

El objetivo de estos escritores, más que criticar la sociedad española de la época, es buscar una reconstrucción del país y de su imagen por medio de valoraciones críticas y reflexivas (Simpson, 2010, p. 1). Por ende, varios de los textos de estos escritores versan sobre una paz anhelada que se esperanza en la venida o el surgir de una nueva España, mejor a la del pasado.

\section{(c) (i) (2)}

La Revista Estudios es editada por la Universidad de Costa Rica y se distribuye bajo una Licencia Creative Commons Atribución-NoComercial-CompartirIgual 3.0 Costa Rica. Para más información envíe un mensaje a revistaestudios.eeg@ucr.ac.cr. 
Especial: Naturaleza amena y naturaleza agreste en las letras hispánicas

En fin, basado en lo estipulado por Cuvardic (2009, p.102), se han establecido las siguientes características de la Generación del $98:^{3}$

- Amor por los viejos pueblos y el paisaje de Castilla.

- Interés por recuperar a los poetas primitivos.

- Rehabilitación de las obras de El Greco y Góngora.

- Acercamiento a la realidad social.

- Recuperación de arcaísmos.

- Curiosidad por las ideas extranjeras.

- Conciencia del desastre de la Guerra del 98.

En fin, respecto a los poetas que conforman esta generación, uno de los más destacados es Antonio Machado, quien, junto con otros de sus compañeros como Miguel de Unamuno y Pío Baroja, encontraron en Castilla el símbolo esperanzador de un rejuvenecimiento de su nación, un pueblo que evoca a un glorioso pasado que se ha perdido y que se desea recuperar (Simpson, 2010, p. 1), apreciándose en varios de sus poemas su visión personal de una España que provoca nostalgia en el yo lírico.

Se ha decidido analizar dos poemas: Retrato y Por tierras de España puesto que son los que más se prestan para cumplir con los objetivos de este artículo.

\footnotetext{
${ }^{3}$ Para respaldar tales características cabe indicar que según Laín (s.f.), en la Generación del 98: Exaltan la libre y alegre juventud de la Castilla primitiva; todos juzgan admirativamente [...] la gloria dominadora y adusta de nuestros dos siglos máximos; todos ven en la ruina de España la consecuencia de una adhesión terca e imposible a las formas de vida del siglo XVII (s.p.).
}

La Revista Estudios es editada por la Universidad de Costa Rica y se distribuye bajo una Licencia Creative Commons Atribución-NoComercial-Compartirlgual 3.0 Costa Rica. Para más información envíe un mensaje a 


\section{RETRATO}

Mi infancia son recuerdos de un patio de Sevilla, y un huerto claro donde madura el limonero; mi juventud, veinte años en tierra de Castilla; mi historia, algunos casos que recordar no quiero.

En cuanto al primer párrafo, se recuerda aquello que se vio o escuchó en un pasado que puede, ya sea, ser mejor o peor. En este caso, debido al contexto de fondo, el yo lírico o alter ego de Machado, remite a una infancia en donde todo fue mejor. Por su parte, según Loiretta Frattale (s.f), los recuerdos desde el periodo clásico están asociados con la memoria, -de la diosa griega Mnemosine- ; con la vista, puesto que, según Juan Eduardo Cirlot (1992), el mirar se asocia con el conocimiento; es decir, el ser humano mira y por ende, incorpora algo nuevo a su mente (Cirlot, 1992, p.306), y con el oído que en el periodo clásico tenía un valor muy importante, que fue sustituido por la vista en el siglo XV cuando la representación empezó a tener más valor (Frattale, s.f, p.163). Por tanto, el yo lírico recuerda a partir de lo que vio, lo cual lo presenta a través de imágenes metafóricas cargadas de angustia.

Tanto memoria como vista y escucha permiten la recolección de hechos o datos mediante imágenes que se almacenan en el sujeto con el pasar del tiempo y que lo van nutriendo ideológicamente (Frattale, s.f, p.163). En sí, los recuerdos son la herramienta para revivir el pasado. Los recuerdos funcionan, algo así como el rito, que al ponerse en función da vida al mito, y no permite que este muera. Por tanto, la acción la acción de recordar, en este primer verso, se convierte en una forma de historiar para el yo lírico, lo cual le permite criticar al presente tras compararlo, a partir de los recuerdos, con su pasado, es decir, su infancia vivida en un patio de Sevilla.

\section{(C) $(00$}

La Revista Estudios es editada por la Universidad de Costa Rica y se distribuye bajo una Licencia Creative Commons Atribución-NoComercial-CompartirIgual 3.0 Costa Rica. Para más información envíe un mensaje a 
Especial: Naturaleza amena y naturaleza agreste en las letras hispánicas

En el segundo verso se alude a un huerto, que se asocia con la tierra en donde ha sido sembrada la esperanza o la ilusión del yo lírico de que su presente mejore, es decir que se encuentre limpio y sano, tal y como estuvo en un pasado, en donde España era dueño de muchas riquezas tras colonizar otras tierras. El huerto juega un destacado papel en este segundo verso en discusión, porque es metáfora de la tierra española o patria. Además, en tal huerto se encuentra un limonero que es símbolo clave y en el siguiente párrafo se dirá el porqué. A su vez, el verbo que da nexo gramatical al segundo verso está en presente de indicativo (madura), es decir, en esa tierra se colocó un limonero para que limpie todo el caos y la impureza que hay en España, pero que no ha sido así porque la acción se está realizando, es decir, el limonero no ha terminado de engendrarse o madurar.

Al igual que el huerto, el limonero cumple una destacada función, este es metáfora de limpieza o purificación. Para certificar tal argumento, se debe recalcar que, según Cristinela Niculescu (2014), el limón fue traído de la India, hasta Grecia y a Egipto, por Alejandro Magno. Años más tarde los españoles lo traerían a América, pero lo importante en ello es señalar que el limón tiene un sentido de limpieza. Por tanto, el yo lírico recuerda un huerto que ahora se encuentra sucio metáfora de caos- y por tanto, necesita ser limpiado para alcanzar el tono azul o sentido de trascendencia tan idealizado por los poetas modernistas, y es a partir del anhelo de purificación en donde surge la necesidad de sembrar un limonero, que tras conectar pasado y presente del yo lírico, se logra saber que el limonero está en estado de maduración, para alcanzar el objetivo de intentar convertir el presente en lo que fuese el pasado u ojalá un tiempo aún mejor.

El tercer verso de igual forma es paralelo al recuerdo, el yo lírico recuerda que vivió durante 20 años en Castilla -metáfora de España-. Tal dato es certero, asociado con la vida de Antonio Machado, él vivió, aproximadamente, 24 años en

La Revista Estudios es editada por la Universidad de Costa Rica y se distribuye bajo una Licencia Creative Commons Atribución-NoComercial-CompartirIgual 3.0 Costa Rica. Para más información envíe un mensaje a 
ISSN 1659-3316

Diciembre 2018

Arroyo Carvajal Yordan

Especial: Naturaleza amena y naturaleza agreste en las letras hispánicas

España, antes de su partida hacia Francia en 1899, en donde conocería al padre del modernismo hispanoamericano Rubén Darío (Biografías y vidas, 2004-2017, parr.2).

Justamente, al unirse el tercer verso con el cuarto, sale a luz que los recuerdos atormentan la psicología del yo lírico, porque hay situaciones que él no quisiera recordar. Tal asunto tiene su lógica, debido a que el yo lírico recuerda su pasado, el cual fue mejor, esto genera una degradación en su psicología o parte sentimental, tras ser consciente de que el pasado en el que él vivió fue mejor al presente caótico, con el cual, le toca luchar a la hora de expresar sus versos

Tal y como se indicó 5 párrafos arriba, los recuerdos son una herramienta para dar vida al pasado, para el yo lírico esta herramienta del recuerdo en realidad es un arma de doble filo, ya que lo hace añorar con nostalgia algo, es decir, un modo de vida o un territorio que ya no posee, porque le han sido quitados con el pasar de las manecillas del reloj. Si el yo lírico no conociera parte de su historia no sentiría tanto dolor, porque no podría comparar el tiempo de ahora (degradado tras la llegada de la modernidad), con el de antes (mejor).

Ni un seductor Mañara, ni un Bradomín he sido

-ya conocéis mi torpe aliño indumentario-, mas recibí la flecha que me asignó Cupido, y amé cuanto ellas puedan tener de hospitalario.

En cuanto a la segunda estrofa, en el quinto verso, el yo lírico, primeramente, alude a un ciudadano de Sevilla que vivió durante el siglo XV, recuérdese que Sevilla fue un sitio en donde Machado residió durante vario tiempo. Según Margot Molina (2010), Miguel Mañara fue un "aristócrata licencioso y soberbio" (párr.1). Además, fue un individuo que "llevó una vida disipada en su juventud" (Molina, 2010, párr.1), sin embargo, a pesar de ello, Mañara fue un

\section{(c) (i) (2) (2)}

La Revista Estudios es editada por la Universidad de Costa Rica y se distribuye bajo una Licencia Creative Commons Atribución-NoComercial-CompartirIgual 3.0 Costa Rica. Para más información envíe un mensaje a revistaestudios.eeg@ucr.ac.cr. 
Especial: Naturaleza amena y naturaleza agreste en las letras hispánicas sujeto que realizó bastantes acciones de bien social, como por ejemplo, ser impulsor de "todo el programa iconográfico de la iglesia de la Santa Caridad" (Molina, 2010, párr.1).

Por otro lado el yo lírico, remite a Bradomín, quien según el artículo periodístico de Susana Acosta (2011), fue un hombre que carecía de belleza física, sentimental y seguidor de la religión católica. Tales datos le brindan verosimilitud al poema.

Ahora bien, tras unir los versos 6, 7 y 8, se logra argumentar que el yo lírico, a pesar de no ser catalogado un personaje importante como los citados por él en sus versos, es un humilde ciudadano que se encuentra dispuesto a colaborar. E yo lírico a pesar de vivir en un entorno que se ha degradado con el pasar del tiempo, no ha perdido sus valores, por tanto, debido a que está anuente a ayudar a los demás, este sujeto se convierte en un símbolo de esperanza para todo el pueblo español, puesto que es un sujeto que vive en un caótico presente, pero que no ha dejado morir los buenos valores que aprendió en su idílico o bello pasado.

Hay en mis venas gotas de sangre jacobina, pero mi verso brota de manantial sereno;

y, más que un hombre al uso que sabe su doctrina, soy, en el buen sentido de la palabra, bueno.

Al igual que en la segunda estrofa, en la tercera el yo lírico se presenta como alguien con gratos valores, y dentro de los preceptos morales de lo que es bueno o malo en una sociedad española del siglo XX, él es un sujeto que puede ser llamado por la sociedad como alguien que es bueno. El yo lírico es de sangre jacobiana, lo cual es metáfora de su sentido demócrata o de lucha ante la opresión o autoritarismo, sin embargo, a pesar de ese sentido de lucha ante la injusticia, el yo lírico menciona que sus versos no tienen ese afán de generar pugnas como lo

\section{(c) (i) (9) (2)}

La Revista Estudios es editada por la Universidad de Costa Rica y se distribuye bajo una Licencia Creative Commons Atribución-NoComercial-CompartirIgual 3.0 Costa Rica. Para más información envíe un mensaje a 
Especial: Naturaleza amena y naturaleza agreste en las letras hispánicas hacen los políticos del pueblo español, sino crear hermandad en su patria y abrir los ojos del ciudadano español para que se enteren de que España ha cambiado, es decir, que el sitio en donde nació el poeta y pasó parte de su adolescencia, ya no es el mismo del presente.

Adoro la hermosura, y en la moderna estética corté las viejas rosas del huerto de Ronsard; mas no amo los afeites de la actual cosmética, ni soy un ave de esas del nuevo gay-trinar.

En la cuarta estrofa, el yo lírico da alusión al movimiento literario Modernismo, caracterizado por su nueva estética y adornos, que justamente permiten al poeta escapar, mediante la belleza de la palabra, del mundo caótico en el que habita, además, en el verso 14, el yo lírico dice que ha dejado atrás las rosas del huerto de Ronsard, lo cual es metáfora del cambio del Romanticismo por el Modernismo, el cual, justamente se entrega de criticar, mediante la palabra, la llegada de la modernidad a un pueblo. En el caso de España, la modernidad convirtió los campos de Castilla en un cementerio, en donde la paz no existe porque las muertes y pobrezas sobresalen. Sin embargo, es interesante ver cómo en el verso 15, el yo lírico se contradice, al decir que no es un ave de esas del nuevo gay-trinar, ello es metáfora del Modernismo.

Tal filosofía presentada por el yo lírico en el verso 15, se asocia con la idea de Antonio Machado de no ser encasillado dentro de un solo movimiento literario, tal y como lo decía Antonio Machado, él tenía un poco de cada movimiento (Literatura Española del siglo XX, s.f).

Desdeño las romanzas de los tenores huecos y el coro de los grillos que cantan a la luna. A distinguir me paro las voces de los ecos, y escucho solamente, entre las voces, una.

\section{(C) $(\Theta \odot$}

La Revista Estudios es editada por la Universidad de Costa Rica y se distribuye bajo una Licencia Creative Commons Atribución-NoComercial-CompartirIgual 3.0 Costa Rica. Para más información envíe un mensaje a 
Especial: Naturaleza amena y naturaleza agreste en las letras hispánicas

En la quinta estrofa se puede apreciar que el yo lírico critica otros cantos, es decir, el de las romanas huecas y el de los grillos, porque para él el mejor canto es el de su poesía, por eso el canto de su poesía es el único que escucha, ya que es el único que vale la pena porque le permite presentar la degradación de una España en la que creció y una España que se ha contaminado con el pasar del tiempo, con las malas administraciones, las pérdidas de las colonias y la llegada de la Modernidad a Europa.

¿Soy clásico o romántico? No sé. Dejar quisiera mi verso, como deja el capitán su espada: famosa por la mano viril que la blandiera, no por el docto oficio del forjador preciada.

En la sexta estrofa hay una filosofía humanística del yo lírico quien anhela alcanzar la inmortalidad o la fama no por su escritura como tal o por ser poeta, sino por el hecho de dejar una contribución en la sociedad, es decir, lograr que la sociedad española abra los ojos a partir del poder de su palabra y por ende, logren un cambio en España, al punto de recuperar el lindo entorno en el que creció el poeta y que se fue degradando con el paso de los años.

Converso con el hombre que siempre va conmigo -quien habla solo espera hablar a Dios un día-; mi soliloquio es plática con este buen amigo que me enseñó el secreto de la filantropía.

En la sétima estrofa, al igual que en la sexta, se logra encontrar una filosofía humanista de parte del yo lírico, quien dice conocer el secreto de la filantropía que justamente, según la RAE (2014), es amor al género humano.

Además, en la sétima estrofa hay una filosofía humanista, la cual se encuentra basada en los parámetros de Jean Paul Sartre, quien en su libro El existencialismo es un humanismo (1997), llega a la conclusión de que el 
Especial: Naturaleza amena y naturaleza agreste en las letras hispánicas existencialismo no busca la negación de Dios como tal, porque si Dios en realidad existiera, el mundo no sería tan caótico, sino que lo que busca esta filosofía es la esencia del ser humano como individuo que puede alcanzar la vida plena o ser para sí, a partir de la sabiduría de sus decisiones o capacidades interiores, y no las de un Dios externo, que si bien existe, está lejos del mundo humano, porque si Dios es perfecto no puede estar en un mundo drástico e imperfecto. Así que, ese buen amigo con el que dialoga el yo lírico, no es Dios, es su otro yo, quien le da la sabiduría necesaria para expresar versos que tienen el objetivo de reconstruir una España que va cada vez más en decadencia. Es el poema de Machado preexistencialista porque durante su época no existía la postura de Sartre que aparece un año después de la Segunda Guerra Mundial.

Y al cabo, nada os debo; debéisme cuanto he escrito.

A mi trabajo acudo, con mi dinero pago

el traje que me cubre y la mansión que habito, el pan que me alimenta y el lecho en donde yazgo.

Y cuando llegue el día del último viaje, y esté al partir la nave que nunca ha de tornar, me encontraréis a bordo ligero de equipaje, casi desnudo, como los hijos de la mar.

En la última u octava estrofa es en donde se logra encontrar uno de los mensajes o filosofías más humanistas del poema "Retrato" (1912), de Antonio Machado, porque el yo lírico menciona que no le debe nada a su sociedad, más bien la sociedad le debe a él por el valor de sus versos, que aunque no son lo que promueve el capitalismo, son más valiosos que cualquier artefacto industrial.

Todo el poema permite argumentar que el yo lírico necesita dinero para pagar los impuestos que le exige su sociedad, para alimentarse y subsistir, es decir, el yo lírico, lamentablemente, presenta al dinero como un material ineludible de vida, del cual el ser humano cada vez depende más, y por eso el yo lírico añora un pasado que fue mejor, porque el pasar del reloj degrada cada vez más a su 
Especial: Naturaleza amena y naturaleza agreste en las letras hispánicas entorno, hace que se pierdan más los valores y las desigualdades crezcan. Pero a pesar de ello, el yo lírico no se deja vencer por el mundo convulso en el que vive, sigue apegado a su filosofía humanista, desde el principio hasta el final del poema en análisis, en donde, en los últimos 4 versos deja claro que cuando muera nada se llevará consigo, porque tal y como lo indica la biblia, de polvo naciste y en polvo te convertirás.

Para el yo lírico el dinero es un factor más de supervivencia, pero nada de lo que se compra con el dinero se lo podrá llevar cuando muera, esto debido a que le tocará partir desnudo en cuerpo, pero lleno en alma, porque a través de sus versos, el yo lírico podrá alcanzar la inmortalidad, mediante el recuerdo de sus compatriotas, lo cual, desde un sentido humanístico, nunca lo podrá conseguir el dinero.

A su vez, con el final que presenta el poema en discusión, se genera un argumento en cuanto a la metáfora que envuelve el título "Retrato" los versos machadianos, justamente, retratan a un yo lírico humanista, quien es consciente, mediante sus recuerdos, de los cambios que ha sufrido para mal su patria, pero que a pesar de ello no ha permitido que sus valores se degraden, ya que deja en sus palabras un tesoro para la humanidad, la cual, de analizar sus versos de manera profunda, se puede enterar de la existencia de una España mejor y que cayó en degradación.

Por tanto, el poeta "Retrato" (1912), es una manera del poeta de escapar de la realidad caótica en la que vive, tras dar vida a su alter ego, a partir del habla del yo lírico en sus versos. Además, el poema permite que el yo lírico utilice el pasado como herramienta para criticar el presente, pero no solo criticarlo, sino retratarse como un sujeto que no ha perdido sus valores a pesar de la degradación de su espacio o entorno.

\section{(C) $(\Theta \odot$}

La Revista Estudios es editada por la Universidad de Costa Rica y se distribuye bajo una Licencia Creative Commons Atribución-NoComercial-CompartirIgual 3.0 Costa Rica. Para más información envíe un mensaje a 
Especial: Naturaleza amena y naturaleza agreste en las letras hispánicas

\section{POR TIERRAS DE ESPAÑA}

El hombre de estos campos que incendia los pinares

y su despojo aguarda como botín de guerra, antaño hubo raído los negros encinares, talado los robustos robledos de la sierra.

En el primer verso, el yo lírico alude a un hombre que incendia los pinares. Los pinos simbolizan la inmortalidad. Cabe decir que este tipo de árbol es un atributo a Baco para los romanos o Dionisio para los griegos, que según Francesc Cardona (2011) y J. Noel (2003), representa el éxtasis y los placeres. Además, Carolina (2009), menciona que el pino es "un emblema de Diana, Júpiter y Venus".

Por su parte, el acto de incendiar se asemeja con el fuego, elemento de la naturaleza que según Juan Eduardo Cirlot (1992), se vincula con el agua y por tanto simboliza la vida o superioridad de esta (pp.208-209), lo cual permite realizar una conexión con la inmortalidad, que se vincula con la regeneración, la cual se simboliza a través del fuego. Los seres inmortales nunca mueren, si desaparecen es para aparecer de vuelta regenerados, recuérdese el mito del ave fénix, quien renace justamente del fuego. A su vez, el fuego posee un carácter dualista, es bueno porque da calor, pero también puede ser malo porque puede destruir. Ejemplo, el acto de robar el fuego para Prometeo fue bueno y malo a la vez; bueno porque con ello les brindó el conocimiento a los humanos, pero malo porque tal burla a Zeus, generó un eterno castigo para Prometeo.

No obstante, al ver que se puede asociar la simbología del pino con la del fuego, se da paso al surgimiento de un ritual, lo cual se fundamenta a partir de lo postulado por Chevalier (1986), quien señala que el fuego es utilizado para la realización de rituales en distintas culturas, incluidas las agrarias, en donde se logra encontrar una relación con el poema en estudio. Según Chevalier (1986), las culturas agrarias utilizan el fuego para realizar ritos de pasaje. Se incendian los campos con el deseo de que estos se regeneren y florezcan verdes y nuevos, para ello el filósofo francés, alude a un mito de la tradición hispanoamericana, cita 
Especial: Naturaleza amena y naturaleza agreste en las letras hispánicas

a los Héroes Gemelos, dioses del maíz en el Popol-Vuh, quienes son metidos en una pira elaborada por sus enemigos para luego renacer "encarnados en el brote verde del maíz" (p.512).

Así que hay dos deseos del tú lírico en el primer verso. El primero es alcanzar la inmortalidad a través del rito o acto de incendiar el pino, símbolo de inmortalidad. Hay un evidente anhelo del tú lírico de trascender, convertirse en un ser inmortal que puede librarse del dolor, la nostalgia y la angustia que generan los campos en donde reside. A su vez, debido a que el pino se asocia con Dionisio, la inmortalidad es vista por el tú lírico como un placer, de allí que incendie los pinares, ya que él quiere ser inmortal, que el espacio bucólico infernal en el que vive no le pueda ganar la partida. Sin embargo, debido a que los campos en los que habita el tú lírico, son vistos a lo largo del poema con degradación, el acto de incendiar los pinares, también se vincula con el deseo de que los campos se regeneren, tal y como lo hacían, a través de los ritos de pasaje, las culturas agrarias a las que alude Chevalier.

Los deseos de inmortalidad y regeneración en el tú lírico se enraízan con la esperanza, la cual se aprecia en el segundo verso, cuando el yo lírico da a conocer que el tú lírico hará lo posible para no marcharse, él no quiere ser vencido por el mal que impera en sus campos producto de los conflictos españoles que hay de fondo.

En el tercer verso el yo lírico alude al recuerdo de un pasado raído, ya que el antaño es un pasado indeterminado, muy lejos del presente. Con ello se está aludiendo a la pérdida de las colonias españolas, porque raído es aquello que se ha gastado por el exceso de su uso. Es decir, los españoles utilizaron todas sus riquezas en demasía y se quedaron sin nada, lo cual ha provocado la degradación de los campos en la actualidad.

Por su parte, en el cuarto verso se dice que el hombre de esos campos ha talado los robledos de la sierra, y según Carolina (2009), el roble es un árbol que

La Revista Estudios es editada por la Universidad de Costa Rica y se distribuye bajo una Licencia Creative Commons Atribución-NoComercial-CompartirIgual 3.0 Costa Rica. Para más información envíe un mensaje a revistaestudios.eeg@ucr.ac.cr. 


\section{Especial: Naturaleza amena y naturaleza agreste en las letras hispánicas}

simboliza lo divino, lo maternal, debido a que está ligado con la madre tierra porque se le atribuía a Hera. A su vez, para Cirlot (1992), el roble también tiene un carácter divino, solo que este autor no se lo atribuye al culto de Hera, sino a Thor, que para los germanos es la representación de Júpiter para los romanos y Zeus para los griegos. El roble debido a su simbología une cielo y tierra (p.389). Por tanto, al conocerse que se talaron los robles de la sierra en un pasado, ello culpa tal acto como el causante de la conversión de los campos de España en un entorno común y corriente, propenso a la entrada del mal, el caos, la catástrofe y demás aspectos negativos, los cuales tratan de evitarse a través de los deseos efímeros del tú lírico y la musicalidad del poema, con rima consonante en los versos pares 1 y 3,2 y 4 .

Hoy ve a sus pobres hijos huyendo de sus lares; la tempestad llevarse los limos de la tierra por los sagrados ríos hacia los anchos mares; y en páramos malditos trabaja, sufre y yerra.

El desgaste de la tierra se vislumbra en la segunda estrofa, ello provoca fragmentaciones y despedidas, porque en el quinto verso el hombre de esos campos ve a sus hijos, huir de los lares. En este caso, hay dos asuntos por analizar, el acto de mirar y la alusión a los lares. Primeramente, con base en lo propuesto por Cirlot (1992), el mirar o ver es símbolo de conocimiento (p.306). A través de la mirada se descubre el mundo. Al mirar el sujeto puede tomar pautas para defenderse ante lo que tiene al frente, al punto de huir de los lares, que según Saray García (2011), cumplen una función importante, porque en la religión romana, estos eran los encargados de proteger a las familias, era un deber rendir culto a estos, siempre y cuando la familia no se fragmentara.

Por tanto, el quinto verso da a conocer que al estar los hijos del tú lírico huyendo de los lares, se denota que hay una fragmentación de la familia en España por dos razones. Primero, se han perdido los valores producto de la 
Especial: Naturaleza amena y naturaleza agreste en las letras hispánicas

entrada de la modernidad, incluso el grupo literario al que pertenece Antonio Machado es conocido como la Generación del desastre (Casanova y Gil Andrés, 2012, p.22). Segundo, los hijos del señor de esos campos huyen porque los lares ya no son seres divinos, es decir, han dejado de proteger las tierras españolas, las cuales en el presente están sumamente degradadas, porque arrastran consigo las malas administraciones políticas que conllevaron a la pérdida de las colonias españolas en el siglo XIX.

El tú lírico mira y por ende, se da cuenta de todo lo negativo que tiene cerca, tal y como lo indica el verso seis, hay toda una tempestad que ha marcado un cambio de ciclo, a tal cambio se alude a través de los ríos y los mares, mencionados en el verso siete, ya que el agua es símbolo dual, marca la transición entre vida y muerte (Cirlot, 1992, pp.54-56). No obstante, para profundizar más en ello, cabe decir que los ríos, como el agua son símbolo dual, ya que corresponden a la fuerza creadora de la naturaleza y el tiempo, así que, marcan el riego de las tierras pero también el olvido y abandono de estas (Cirlot, 1992, p.389). Por su lado, el mar también es símbolo dual, este es considerado como fuente de vida pero también final de ella, regresar al mar es retornar al líquido amniótico de la madre, morir (Cirlot, 1992, p.298). Por tanto, el tú lírico es testigo del cambio de ciclo que ha sufrido su tierra, la cual ha pasado de lo fértil (río) a lo mortífero, angustiante o caótico (traslado hacia el mar).

En la segunda estrofa hay un proceso de observación que culmina en el verso 8 cuando el yo lírico es testigo de que la tierra del tú lírico se convierte cada vez más en una cárcel, en donde la degradación junto con el trabajar para sufrir son una costumbre, esto tras ver que el tú lírico es un ser que depende absolutamente de su tierra y por ende, si esta está en decadencia, su felicidad y su progreso también. Incluso, el yo lírico es testigo de la fuerza o poder de la tierra

\section{(c) (i) (2)}

La Revista Estudios es editada por la Universidad de Costa Rica y se distribuye bajo una Licencia Creative Commons Atribución-NoComercial-CompartirIgual 3.0 Costa Rica. Para más información envíe un mensaje a 
Especial: Naturaleza amena y naturaleza agreste en las letras hispánicas

sobre el ser humano, tras decir que el hombre de esos campos de España trabaja, sufre y yerra en un sitio al cual se le ajusta a la medida el adjetivo maldito.

Es hijo de una estirpe de rudos caminantes, pastores que conducen sus hordas de merinos a Extremadura fértil, rebaños trashumantes que mancha el polvo y dora el sol de los caminos.

En la tercera estrofa el yo lírico da a conocer que el tú lírico proviene de una familia de luchadores, tras utilizar el adjetivo plural -rudos- y el sustantivo plural caminantes-, sin embargo, eso de nada le ha servido porque la feroz tierra en donde vive devora el carácter luchador del tú lírico. En el verso 10 se menciona que el tú lírico es hijo de pastores que conducen tropas de lucha. Los pastores siempre se han caracterizado por orientar a sus ovejas, que en este caso simbolizan al pueblo, por su parte, Cirlot (1992), menciona que los pastores son símbolo de poder debido a que tienen la habilidad de guiar. Además el rebaño representa las fuerzas cósmicas (p.355).

Sin embargo, el hombre de estos campos que menciona el yo lírico, no puede ser un buen pastor como sus padres porque su tierra no le permite realizar tal labor, su entorno no es un sitio inadecuado para criar ovejas. Por tanto, con ello el yo lírico alude al mito de la España que fue mejor, es decir al recuerdo de una tierra que sí permitía el buen cuido de las ovejas, lo cual en el presente se ha imposibilitada y por tanto, el tú lírico ha perdido el rol de su familia por opresión de su tierra. Incluso en el verso once se menciona el desplazo de los rebaños rebaños trashumantes- ya que es necesario un cambio de ciclo y de ubicación de estos. Al movilizarse tales rebaños, surge un sentido de esperanza e idealismo porque se mancha el polvo que simboliza la muerte (Cirlot, 1992, p.370) y se dora el sol que simboliza o representa el mayor acto heroico (Cirlot, 1992, pp. 416-417). El acto de cambiar de sitios los rebaños es dar paso a una transición que se espera sea mejor.

\section{(c) (i) (9) (2)}

La Revista Estudios es editada por la Universidad de Costa Rica y se distribuye bajo una Licencia Creative Commons Atribución-NoComercial-CompartirIgual 3.0 Costa Rica. Para más información envíe un mensaje a 


\section{Especial: Naturaleza amena y naturaleza agreste en las letras hispánicas}

Pequeño, ágil, sufrido, los ojos de hombre astuto, hundidos, recelosos, movibles; y trazadas cual arco de ballesta, en el semblante enjuto de pómulos salientes, las cejas muy pobladas.

En la cuarta estrofa se califica al tú lírico como alguien que posee los ojos hundidos y recelosos, es decir, aspectos negativos, por ende, cabe decir que los ojos se vinculan con la mirada que simboliza el conocimiento (Cirlot, 1992, p. 339). El tú lírico se encuentra en un entorno en donde el conocimiento no es su amigo, a él no le sirve saber o conocer porque el conocimiento le hará ver la realidad caótica en la que vive, es decir que sus fieles acompañantes son la tristeza, el dolor del recuerdo y la degradación de su vida, la cual se desvanece junto con su tierra, porque hasta el momento, el poema de Machado da a entender que el hombre depende totalmente de su tierra, es decir, sin ella, el hombre no es hombre, sino un simple pedazo de polvo. Incluso es interesante cómo en los versos 15 y 16 se describe al tú lírico como una persona muy flaca, maltratada por la vida y de cejas gruesas que según Francisca Balduzzi (2013), son reflejo de personas que necesitan estar activas, por tanto el tú lírico es un sujeto que vive en constante lucha con su tierra, la cual a través de todo lo negativo que hay sobre ella, trata de degradar al sujeto y robarle todas sus energías para que muera junto con esta.

Abunda el hombre malo del campo y de la aldea, capaz de insanos vicios y crímenes bestiales, que bajo el pardo sayo esconde un alma fea, esclava de los siete pecados capitales.

La quinta estrofa es vital para entender por qué los campos están degradados, puesto que el yo lírico da a conocer que en esas tierras abundan los hombres malos y capaces de cometer crímenes y caer en vicios y en los siete pecados capitales, por ende, la degradación del campo presentada por el tú lírico 
Especial: Naturaleza amena y naturaleza agreste en las letras hispánicas

a través de los versos anteriores, no ha sido espontánea, sino ocasionada por todos los hombres malos que como lo dice el verso 19, esconden un alma fea. La tierra se convirtió en un reflejo de la humanidad, razón por la cual era mejor en un pasado, ya que los ciudadanos se comportaban distinto, en España no abundaba la pobreza, las altas tasas de mortalidad y el exceso de violencia (Casanova y Gil Andrés, 2012, p.29).

Los ojos siempre turbios de envidia o de tristeza, guarda su presa y libra la que el vecino alcanza; ni para su infortunio ni goza su riqueza; le hieren y acongojan fortuna y malandanza.

El numen de estos campos es sanguinario y fiero; al declinar la tarde, sobre el remoto alcor, veréis agigantarse la forma de un arquero, la forma de un inmenso centauro flechador.

Veréis llanuras bélicas y páramos de asceta -no fue por estos campos el bíblico jardín- ; son tierras para el águila, un trozo de planeta por donde cruza errante la sombra de Caín.

Las últimos tres estrofas del poema en discusión, terminan de certificar que el sitio en donde vive el tú lírico es un entorno cargado de maldad, caos y fealdad. En la sexta estrofa se observa a un tú lírico que se encuentra en un estado severo de tristeza debido a sus malas experiencias. Tal tú lirico es la naturaleza, la cual ha incorporado un sentido o comportamiento de barbarie -sanguinario y fiero-.

Además, en la sétima estrofa se alude a la aparición de un inmenso centauro flechador. El centauro según Cirlot (1992, p. 124), y Chevalier (1986, p. 272), simboliza o representa la parte interior, compulsiva o bestial del sujeto, que no puede ser controlada por el espíritu. En este caso, el centauro flechador se convierte en un tipo de protector de la tierra española, un ser bestial que está dispuesto, a como dé lugar, expulsar a todo sujeto de alma fea, producto de todo el daño reprimido que lleva en su recuerdo, por ejemplo, recordar una España que

\section{(C) $(\Theta \odot$}

La Revista Estudios es editada por la Universidad de Costa Rica y se distribuye bajo una Licencia Creative Commons Atribución-NoComercial-CompartirIgual 3.0 Costa Rica. Para más información envíe un mensaje a 
Especial: Naturaleza amena y naturaleza agreste en las letras hispánicas fue mejor y que ha pasado a ser solo historia. No obstante, el centauro posee la habilidad de la medicina gracias a la instrucción de Apolo (1986, p. 272).

El centauro al que alude el yo lírico no es un ser mítico cualquiera, sino un flechador, para ello se debe argumentar que el hecho de que el centauro sea flechador no es pura casualidad, remite a la inversión de papeles de un mito griego mencionado por Chevalier (1986, p. 272). Quirón había sido dañado en su pie, para siempre, por una flecha. Quirón podía eliminar los daños de su parte corporal, no así su herida en el pie, porque esta simbolizaba un daño en el alma.

Los papeles del mito se invierten en el poema de Machado, el centauro no quiere ocasionar un mal en los humanos, como sucedió con él cuando lo flecharon en su pie, sino luchar por sanar a la humanidad a través de su flecha y así dar a conocer su atributo de médico, del cual según Chevalier (1986), Quirón se había obstinado en un pasado (p. 272). La flecha es utilizada por el Centauro como herramienta humanística de lucha porque según Cirlot (1992, p. 82), las flechas simbolizan la luz solar y la purificación. Así que el centauro flechador es visto como un guardia que quiere limpiar la suciedad de su tierra, a través de la eliminación de la parte bestial de los ciudadanos españoles que han destruido España producto de la pérdida de valores y malas administraciones. Por tanto, se está en presencia de un centauro humanizado, producto del ideal humanístico de la Generación del 98 española mencionado por Cuvardic (2009), pero que puede sacar su parte bestial si la flecha purificadora no surge efecto, cumpliéndose con ello el sentido ambivalente que posee el centauro -mitad hombre, mitad caballo-.

Es justo y necesario que haya alguien que luche por sanar los campos de España como el centauro flechador porque estos han pasado por mucho dolor y por tanto, tal y como lo señala el verso 30 , no son para nada un paraíso del edén, y si algo tienen que ver con el elemento bíblico es en cuanto a la sombra de Caín a la que se alude en el último verso. Tras el yo lírico mencionar que por esas tierras corre la sombra de Caín, lo que se quiere dar a entender es que son tan

\section{(c) (i) (9) (2)}

La Revista Estudios es editada por la Universidad de Costa Rica y se distribuye bajo una Licencia Creative Commons Atribución-NoComercial-CompartirIgual 3.0 Costa Rica. Para más información envíe un mensaje a revistaestudios.eeg@ucr.ac.cr. 
Especial: Naturaleza amena y naturaleza agreste en las letras hispánicas

caóticas estas tierras que allí abundan los muertos. Los campos de España mencionados por el yo lírico se asemejan con el infierno.

En el verso 29 se dice que son tierras de águila, lo cual es muy simbólico, ya que el águila se caracteriza por devorar a sus presas y eso es justamente lo que hacen estas tierras, devorar a sus ciudadanos, quienes han sido los encargados de generar una catastrófico cambio de pasado a presente sin darse cuenta de que los elementos de la naturaleza tiene pleno poder sobre la humanidad, de allí que el yo lírico mencione que se verán llanuras bélicas, ya que la tierra está dispuesta a luchar, lo cual deja un mensaje humanístico. Inclusive, son tierras para el águila porque el águila es símbolo de lo paterno y se asocia con el sol. Por tanto, el águila se puede vincular con el esposo indicado para Gea o la naturaleza, esto debido a su espíritu de lucha.

\section{CONCLUSIONES}

El análisis de los poemas "Retrato" y "Por las tierras de España" dan a conocer un estilo de escritura que refleja la angustia, el dolor y la degradación de un país como España que llegó a ser una gran potencia y que producto de la pérdida de las colonias, malas administraciones, conflictos políticos, enfermedades y demás, pasó a formar parte de un pasado, el cual, atormenta la psicología del yo lírico, ya que este vive en un presente que no se compara con el lugar donde creció.

En ambos poemas analizados y tras hacer lectura de todos los poemas de Campos de Castilla (1912), se debe destacar la constante presencia de nostalgia en el yo lírico.

A pesar de que su espacio o entorno influye en sus sentimientos, el yo lírico no pierde la lucha y presenta la esperanza como un arma para conseguir en el futuro una mejora de España.

\section{(c) (i) (2)}

La Revista Estudios es editada por la Universidad de Costa Rica y se distribuye bajo una Licencia Creative Commons Atribución-NoComercial-CompartirIgual 3.0 Costa Rica. Para más información envíe un mensaje a 
Especial: Naturaleza amena y naturaleza agreste en las letras hispánicas

Los poemas machadianos sirven de nexo, porque conectan el pasado con el presente y con ello logran historiar o dar paso al rito, ya que la España mejor o idílica del pasado es concebida por estudiosos de la literatura como un tópico mitológico. Se denota el afán de los poemas de Machado de hacer que los lectores u oyentes, al escuchar los versos de Machado, sepan que en la historia hubo una España que fue mejor y que en el siglo XX se anhelaba que retornara a ellos, es decir, que España volviera a nacer, lo cual lo siguen esperando los españoles hasta hoy, tras seguir vigente el mito de la España mejor del pasado, que empezó a crecer con Miguel de Cervantes Saavedra, ícono de la literatura tanto española como universal.

Se ha demostrado que las metáforas y símbolos que conforman los poemas de Antonio Machado llevan una carga semántica de tristeza, soledad y tristeza, pero que, a su vez, llevan consigo un poco de esperanza, ya que el yo lírico anhela una España mejor para su futuro, razón por la cual no se deja consumir por el presente caótico en el que vive.

El yo lírico no cesa en los versos y muestra los valores e ideologías morales que pudo aprender en el pasado. No obstante, presenta elementos metafóricos y simbólicos para mostrar que España puede salir adelante en el futuro.

A través de los versos que conforman el poemario en estudio, el yo lírico habla por toda una sociedad española que pide con lágrimas el retorno al pasado, o un cambio de ciclo, que les permita romper el binomio presente (oscuro) pasado (idílico), que trae consigo dos enemigos de vida llamados nostalgia y frustración, escondidos a través de muchas metáforas y símbolos de la naturaleza buscan el despertar de un pueblo o través del humanismo y el uso de la razón.

Queda demostrado que los versos machadianos son reflejo del dolor, la tragedia y demás elementos oscuros en los que se ve inmerso el yo lírico, quien

La Revista Estudios es editada por la Universidad de Costa Rica y se distribuye bajo una Licencia Creative Commons Atribución-NoComercial-Compartirlgual 3.0 Costa Rica. Para más información envíe un mensaje a revistaestudios.eeg@ucr.ac.cr. 
Especial: Naturaleza amena y naturaleza agreste en las letras hispánicas se presenta como un niño que creció en campos idílicos del pasado, y que vive en el presente como un joven humanista que siente el dolor de su madre en carne propia, porque su alma mater es España, quien se ha convertido en una naturaleza agreste justamente para defenderse del daño que le causan los seres humanos.

\section{REFERENCIAS BIBLIOGRÁFICAS}

Acosta, S (2011). "Como el marqués de Bradomín, soy feo, católico y sentimental». Diario la voz de Galicia. Recuperado de: \{(http://www.lavozdegalicia.es/noticia/coruna/2011/10/02/marquesbradomin-feo-catolico-sentimental/0003_201110H2C12995.htm)\}.

Balduzzi, F (2013). Lo que dicen tus cejas de ti. Recuperado de: $\{$ (https://www.belelu.com/2013/10/lo-que-dicen-tus-cejas-de-ti/)\}.

Biografías y vidas (2004-2017). Antonio Machado. Recuperado de: $\{$ (https://www.biografiasyvidas.com/biografia/m/machado.htm)\}.

Cardona, F (2011). Mitología griega. España, Barcelona: Brontes.

Carolina (2009). Los símbolos y los signos. Recuperado de: $\{$ (http://simbolosysignos.blogspot.com/2009/01/arboles.html)\}.

Casanova, J y Andrés, C (2012). Breve historia de España en el siglo XX. España, Barcelona: Ariel.

Cirlot, J (1992). Diccionario de símbolos. España, Barcelona: Labor.

Cuvardic, D. (2009). El debate Modernismo-Generación del 98. Revista Reflexiones, 88 (2), pp. 101-112.

Chevalier, J. (1986). Diccionario de los símbolos. Barcelona: Editorial Herder.

Frattale, $L$ (s.f). Los ojos de la memoria: recuerdos, sueños y ensueños en la obra poética del primer Alberti. Centro virtual Cervantes. Pp.163- 174.

\section{(c) (i)(2)}

La Revista Estudios es editada por la Universidad de Costa Rica y se distribuye bajo una Licencia Creative Commons Atribución-NoComercial-CompartirIgual 3.0 Costa Rica. Para más información envíe un mensaje a 
Especial: Naturaleza amena y naturaleza agreste en las letras hispánicas

García, S (2011). Los lares romanos, dioses del hogar. Recuperado de: $\{$ (http://sobreleyendas.com/2011/10/10/los-lares-romanos-dioses-delhogar/)\}.

Innman, E. (1989). El concepto de la «Generación de 1898» y la historiografía literaria.

Recuperado

de \{(http://cvc.cervantes.es/literatura/aih/pdf/10/aih_10_2_089.pdf)\}

Laín, P. (s.f.). La generación del 98 y el problema de España. Recuperado de \{(http://www.cervantesvirtual.com/obra-visor/la-generacion-del-98-y-elproblema-de-espaa/html/dcd543b4-2dc6-11e2-b417000475f5bda5_5.htm|\#l_0_)\}.

Literatura española del siglo XX (s.f). La obra poética de Antonio Machado. Recuperado de: $\{$ (http://www.auladeletras.net/material/machado.pdf)\}.

Literatura española del siglo XX (s.f). La obra poética de Antonio Machado. Recuperado de: $\{$ (http://www.auladeletras.net/material/machado.pdf)\}.

Niculescu, C (2014). Tu guía esotérica. Recuperado de: $\{$ (http://www.tuguiaesoterica.com/blog/plantas-milagrosas/el-limon/a452)\}.

Molina, M (2010). El enigma de Miguel Mañara. Diario L país. Recuperado de: \{(https://elpais.com/diario/2010/04/14/andalucia/1271197336_850215.html)\}. Noel, J (2003). España, Barcelona: Edicomunicación.

Real Academia Española (2014). 23. Edición. Recuperado de: \{(http://dle.rae.es/?id=Htitoxg[consultado el 10 de Julio de 2017)\}.

Sartre, J (1997). El existencialismo es un humanismo. Costa Rica, San José: Guayacán Centroamericana.

Saavedra, M (2004). El ingenioso hidalgo Don Quijote de la Mancha. España, Madrid: Espasa Calpe.

Simpson, D. (2010). Algunos vínculos de la simbología paisajista de Castilla en Unamuno y Antonio Machado. Revista de estudios sobre Antonio Machado. Pp. 1-7.

\section{(c) (i) (-)}

La Revista Estudios es editada por la Universidad de Costa Rica y se distribuye bajo una Licencia Creative Commons Atribución-NoComercial-CompartirIgual 3.0 Costa Rica. Para más información envíe un mensaje a revistaestudios.eeg@ucr.ac.cr. 